\title{
Long noncoding RNAs, emerging players in muscle differentiation and disease
}

\author{
Maria Victoria Neguembor, Mathivanan Jothi and Davide Gabellini*
}

\begin{abstract}
The vast majority of the mammalian genome is transcribed giving rise to many different types of noncoding RNAs. Among them, long noncoding RNAs are the most numerous and functionally versatile class. Indeed, the IncRNA repertoire might be as rich as the proteome. LncRNAs have emerged as key regulators of gene expression at multiple levels. They play important roles in the regulation of development, differentiation and maintenance of cell identity and they also contribute to disease. In this review, we present recent advances in the biology of IncRNAs in muscle development and differentiation. We will also discuss the contribution of IncRNAs to muscle disease with a particular focus on Duchenne and facioscapulohumeral muscular dystrophies.
\end{abstract}

Keywords: Chromatin, DMD, FSHD, Muscular dystrophy, ncRNA, Repeat

\section{Review}

Long non protein-coding RNAs (IncRNAs)

In mammals, the vast majority of the transcriptional output is noncoding [1]. While $75 \%$ of the genome is transcribed, only $2 \%$ encodes for proteins [2]. Non proteincoding RNAs (ncRNAs) are operationally divided in two classes according to their size. Small ncRNAs are below 200 bp and include transfer RNA (tRNA), ribosomal RNA (rRNA), small nuclear RNAs (snRNA), small nucleolar RNAs (snoRNA), microRNAs, siRNAs and Piwi-interacting RNAs (piRNA) [3-7]. Long ncRNAs (lncRNAs) include all ncRNA transcripts greater than 200 bp with little or no coding potential. Although discovered relatively recently, lncRNAs are considered the most numerous and functionally diverse class of RNAs [8]. Up to 15,000 lncRNAs have been identified so far [9] and, as the number constantly increases, the lncRNA assortment might turn out to be as rich as the proteome.

LncRNAs loci are often in close association with protein-coding genes as they are encoded from exonic or intronic sequences in both sense and antisense orientation or even from gene regulatory regions [10]. LncRNAs can also arise from intergenic regions including repetitive sequences [11]. Most lncRNAs are transcribed by RNA

\footnotetext{
* Correspondence: gabellini.davide@hsr.it

Dulbecco Telethon Institute at San Raffaele Scientific Institute, Division of Regenerative Medicine, Stem cells, and Gene therapy, DIBIT2, 5A3, Via Olgettina 58, 20132 Milano, Italy
}

polymerase II and may share mRNA-like features such as 5'cap, polyA tail and splicing sites [12,13]. Alternatively, non-polyadenylated lncRNAs are likely generated by RNA polymerase III $[14,15]$.

In terms of transcriptional profile, IncRNAs are generally expressed at lower levels than protein-coding transcripts and, compared to the latter, their pattern of expression is more developmental stage- and cell typespecific $[2,16]$. The intrinsic nature and complex secondary structures of IncRNAs enable them to specifically interact with DNA, RNA and proteins. Since lncRNAs are localized both in the nucleus and the cytosol, they can act at virtually every level of gene expression $[17,18]$.

\section{LncRNA, a molecular 'passepartout'}

LncRNAs can be divided into multiple functional categories based on the site of action and the level of gene expression at which they act. However, as our knowledge of IncRNAs increases, new functional groups emerge and the distinction between classes is not always adequate. Here, we present a very brief classification to provide a framework for the examples of lncRNAs acting in muscle differentiation and disease later described.

Nuclear lncRNAs can be subdivided into cis-acting RNAs that work in proximity to their site of transcription, and trans-acting RNAs that operate at distant loci. Both cis- and trans-acting lncRNAs can activate or repress transcription through the recruitment of chromatin 
remodelers and modifiers, thus shaping the chromatin status of a particular locus or even of an entire chromosome (Figure 1A) [19-24]. Besides, lncRNAs are able to recruit or prevent the binding of the transcriptional machinery and transcription factors directly impacting the transcriptional output of a region (Figure 1B) [25-28]. Among these, enhancer RNAs (eRNAs), are encoded by extragenic enhancer regions and promote transcription of surrounding genes [29-32]. LncRNAs also participate in co- and post-transcriptional regulation in the nucleus. For example, lncRNAs can interact with the splicing machinery or directly with nascent mRNAs to guide particular splicing events (Figure 1C) [33-35]. In addition to the cis versus trans distinction, lncRNAs can shape the subnuclear architecture in different ways. Certain lncRNAs regulate chromosome looping, favoring or disrupting chromosomal interactions (Figure 1D) [36,37]. Others act as structural scaffolds for the formation and regulation of

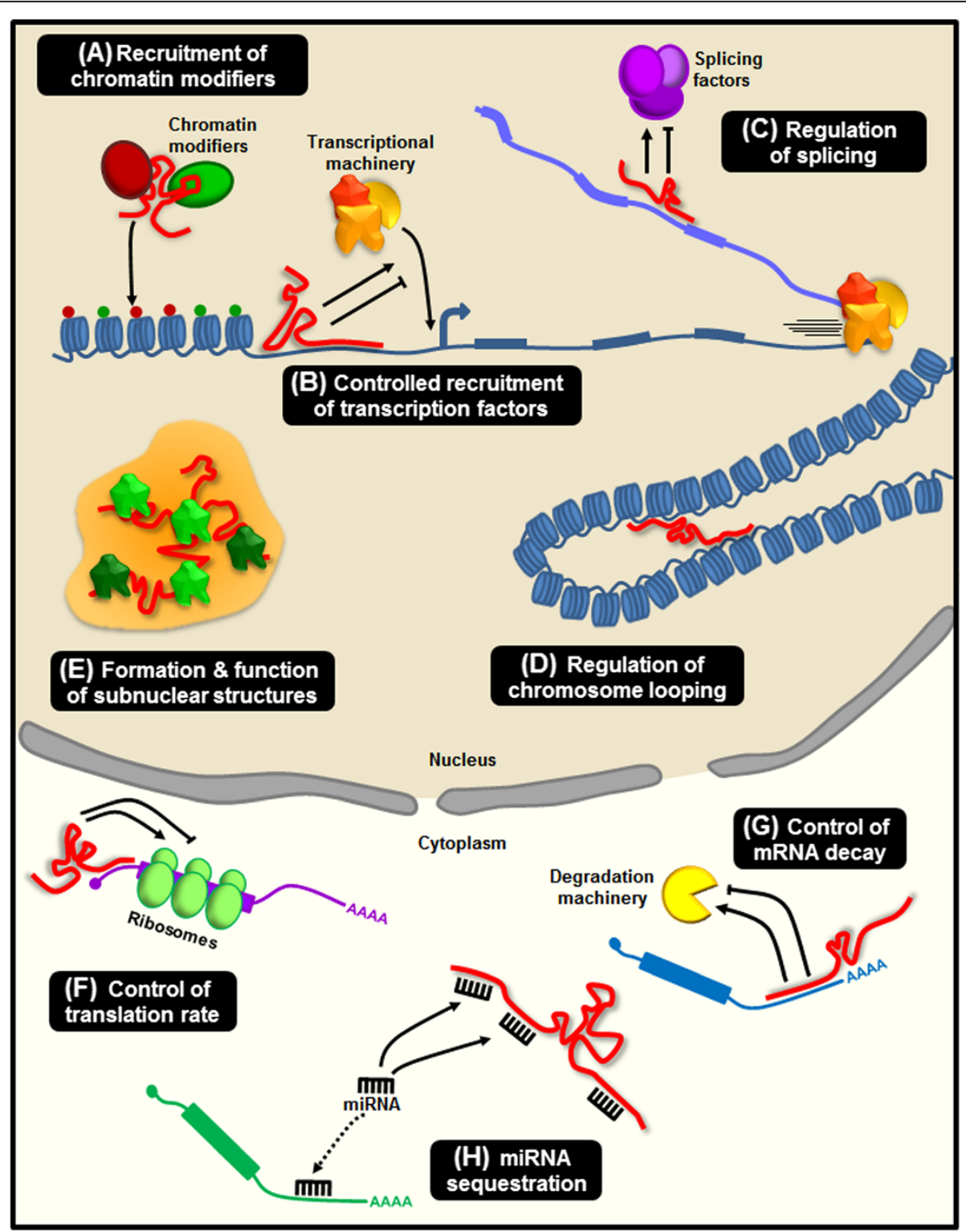

Figure 1 Mechanisms for long noncoding RNA (IncRNA) function. (A) LncRNAs (in red) are able to recruit chromatin modifiers mediating the deposition of activatory (green dots) or repressive (red dots) histone marks. (B) LncRNAs control the recruitment of transcription factors and core components of the transcriptional machinery. (C) LncRNAs can directly bind mRNAs and modulate splicing events. (D-E) LncRNAs participate in the higher order organization of the nucleus by mediating chromatin looping (D) and as structural components for the formation and function of nuclear bodies (E). (F) LncRNAs control translation rates favoring or inhibiting polysome loading to mRNAs. (G) LncRNAs modulate mRNA decay protecting mRNA from degradation or, alternatively, mediating the recruitment of degradation machinery. (H) LncRNAs can act as miRNA sponges, thus favoring the expression of the mRNAs targeted by the sequestered miRNA. 
nuclear compartments such as speckles [33], paraspeckles [38] and Polycomb bodies [39] (Figure 1E).

In the cytoplasm, IncRNAs influence translational output in different ways. Firstly, they can modulate the translational rate by regulating polysome loading to an mRNA molecule (Figure 1F) or through the control of internal ribosomal entry sites (IRES) [40-42]. Secondly, they can regulate gene expression by reducing or stimulating mRNA decay (Figure 1G) [43,44]. A particular class of cytoplasmic lncRNAs, the competing endogenous RNAs (ceRNA), regulates both the translation and the degradation rates of mRNAs by acting as molecular sponges for miRNAs, thus modulating the repressive activity of miRNA on their mRNA targets (Figure 1H) [45-49].

Altogether, lncRNAs exhibit remarkable functional flexibility and tightly regulated expression that confer on them an enormous potential as fine tuners of cell function and identity. Due to their versatility, they are able to control different aspects of cellular development, from stem cell maintenance to commitment and differentiation and we anticipate their biological role in a great variety of cell types to be uncovered in the near future [50]. In this review, we will focus on the fascinating discoveries regarding the role of lncRNAs in muscle differentiation and disease, with a particular focus on Duchenne muscular dystrophy (DMD) and facioscapulohumeral muscular dystrophy (FSHD).

\section{LncRNAs in myogenic differentiation}

Myogenesis is the process where progenitor cells give rise to myoblasts that fuse onto multi-nucleated myofibers endowed with contractile ability. This complex and tightly regulated process starts from extra/intra cellular signals impinging on the myogenic transcription program. An enormous literature provides evidence that the myogenic gene expression program is orchestrated by a transcriptional hierarchy, including the Myogenic Regulatory Factors (MyoD, Myf5, Myogenin, and MRF4) and the Myocyte Enhancer Factor-2 (MEF2A-D) families of transcription factors (reviewed in [51] and [52]). In a stagespecific manner, these factors act in coordination with other transcriptional regulators, including epigenetic factors, to execute the muscle differentiation program [53]. Still, this scenario is not complete as new players are gradually emerging. Indeed, there is increasing evidence that ncRNAs are also part of the muscle regulatory network. So far, miRNAs are the most extensively studied and characterized [54]. However, in the last years lncRNAs are emerging as critical regulators of muscle differentiation (Table 1).

\section{LncRNAs mediating the activity of chromatin modifiers and transcription factors}

An increasing body of work indicates that many nuclear lncRNAs regulate the activity of enhancers at various levels. Enhancers are distal regulatory elements that play an essential role for the proper temporal and tissuespecific expression of protein-coding genes. Typically, active enhancers display increased chromatin accessibility and are enriched for monomethyl histone $\mathrm{H} 3$ lysine 4. (H3K4me1) and acetylated H3K27 (H3K27ac). Intriguingly, RNA polymerase II (RNAPII) is also enriched at active enhancers where it drives localized transcription of lncRNAs called enhancer-derived RNAs (eRNAs) $[31,66]$. Many eRNAs regulate enhancer/promoter communication by directly recruiting chromatin modifiers and remodelers and the transcriptional machinery, thus favoring

Table 1 Long noncoding RNAs (IncRNAs) involved in muscle differentiation

\begin{tabular}{|c|c|c|c|c|c|}
\hline LncRNA & Site of action & Function & Effector molecule & $\begin{array}{l}\text { Regulation during } \\
\text { muscle differentiation }\end{array}$ & References \\
\hline eRNAs ( ${ }^{C E}$ and DRR RNAs) & Nucleus & Transcriptional activation & MyoD & Up & [30] \\
\hline Gt/2/Meg3 & Nucleus & Epigenetic repression & PRC2 & Up & {$[55,56]$} \\
\hline H19 & $\begin{array}{l}\text { Nucleus and } \\
\text { cytoplasm }\end{array}$ & Epigenetic repression, miRNAs sponge & PRC2, let-7 miRNAs & Up & {$[57]$} \\
\hline Linc-MD1 & Cytoplasm & miRNAs sponge & $\mathrm{HuR}$ & Up & {$[46,58]$} \\
\hline Malat1 & Nucleus & $\begin{array}{l}\text { Epigenetic repression, pre-mRNA } \\
\text { splicing }\end{array}$ & $\begin{array}{l}\text { Cbx4 and SR family } \\
\text { of splicing factors }\end{array}$ & Up & {$[59]$} \\
\hline Neat1 & Nucleus & $\begin{array}{l}\text { Structural integrity of nuclear } \\
\text { paraspeckles }\end{array}$ & $\begin{array}{l}\text { Various RNA-binding } \\
\text { proteins }\end{array}$ & Up & {$[60]$} \\
\hline Nctcl & Nucleus? & Unknown & Unknown & Up & {$[61]$} \\
\hline SRA & Nucleus & Scaffold factor & MyoD & Up & {$[62,63]$} \\
\hline $\begin{array}{l}\text { SINE containing } \\
\text { InCRNAs }\end{array}$ & Cytoplasm & mRNA decay & STAU1 and STAU2 & Up & {$[64]$} \\
\hline Yams & Nucleus & Transcriptional activation & Unknown & Up/down & {$[65]$} \\
\hline
\end{tabular}

eRNAs: enhancer RNAs; ${ }^{C E}$ and ${ }^{D R R}$ RNAs: Core Enhancer and Distal Regulatory Region RNAs; Gt12/Meg3: Gene trap locus 2/Maternally expressed gene 3; Malat1: Metastasis associated lung adenocarcinoma transcript 1; Neat1: Nuclear enriched abundant transcript 1; Nctc1: Noncoding transcript 1; SRA: Steroid receptor RNA Activator; SINE containing IncRNAs: Short Interspersed Elements containing IncRNAs; Yams: YY1-associated muscle lincRNAs. 
the activation of gene expression in cis or in trans (Figure 1B) [29,32,36,67-70]. Recently, a key role for eRNAs in the regulation of muscle differentiation was uncovered [30]. In myotubes, ChIP-seq analyses revealed that the myogenic regulatory factors MyoD and MyoG display a very similar genome-wide binding profile and are mostly associated with extragenic regions, many of which exhibit eRNA features [30]. Several of these eRNAs are preferentially localized to the nucleus and are mainly regulated by MyoD, as MyoG silencing has a marginal effect on their expression [30]. In turn, two eRNAs generated by upstream regulatory regions of $M y o D(C E$ and $D R R)$ regulate the expression of $M y o D$ and $M y o G$ (Figure 2A and Table 1) [71,72]. Both eRNAs are involved in the activation of gene expression, but they differ in their mode of action. While the ${ }^{C E} R N A$ functions in cis to activate expression of $M y o D,{ }^{D R R} R N A$ works in trans to promote $M y o G$ transcription and muscle differentiation (Figure 2A). At their site of action, both eRNAs mediate increased chromatin accessibility and recruitment of RNAPII [30]. Collectively, these findings suggest that eRNAs regulate myogenesis by directing chromatin-remodeling events,

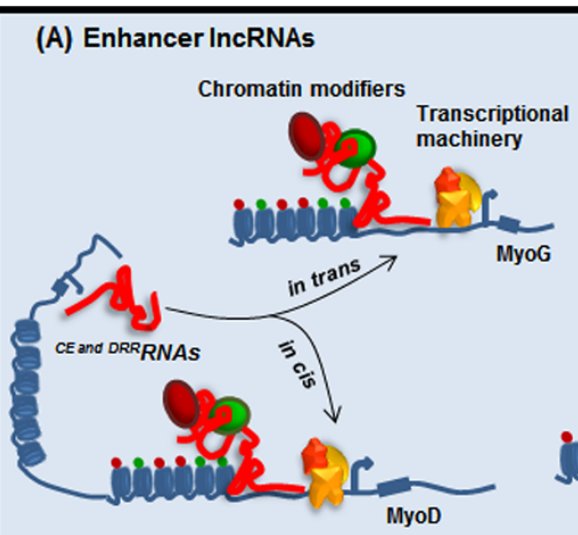

(B) Scaffold IncRNAs

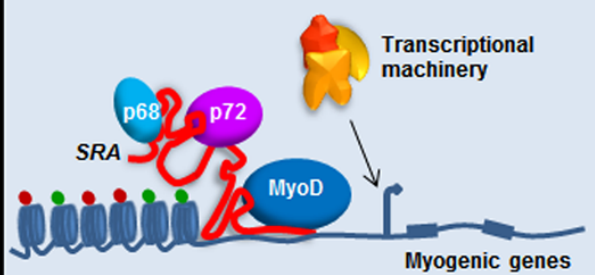

(C) LncRNAs recruiting epigenetic regulators

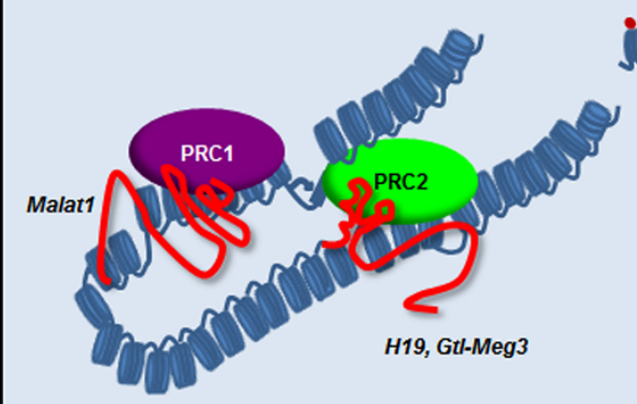

(D) IncRNAs as microRNA sponges

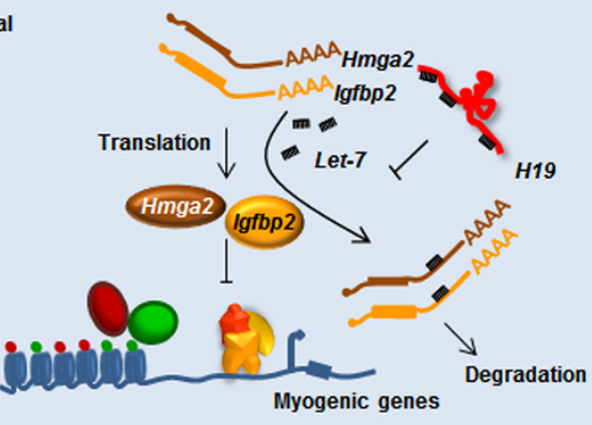

(E) LncRNAs regulating mRNA decay

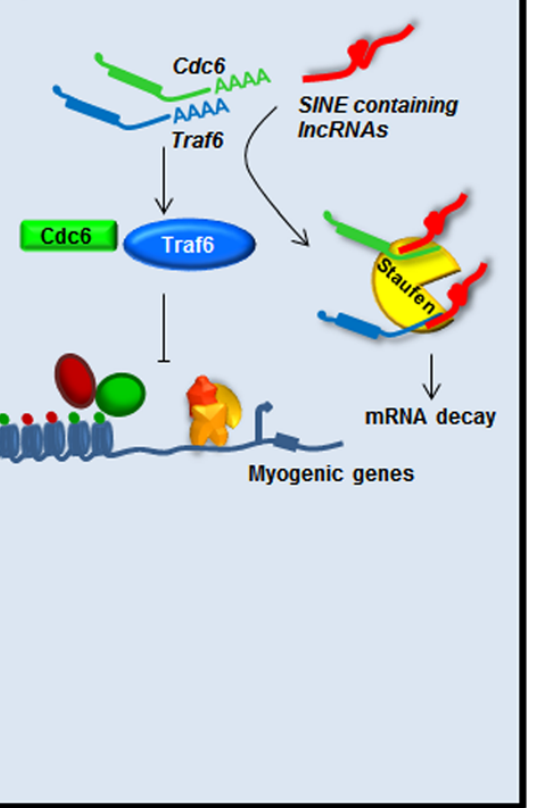

Figure 2 Distinct roles of long noncoding RNAs (IncRNAs) in muscle differentiation. (A) Enhancer RNAs (eRNAs) ${ }^{C E}$ and DRR $R N A s$ Can induce expression of myogenic regulators MyoD and MyoG acting in cis or in trans, respectively. (B) LncRNA SRA acts as a scaffold molecule for MyoD, p68 and p72 at the promoter region of myogenic genes to activate their expression. (C) LncRNAs Malat1, H19 and Gtl-Meg3 interact with PRC1/2 complex to modulate their target genes. (D) As a molecular sponge $\mathrm{H} 19$ inhibits let-7 mediated mRNA degradation of myogenic negative regulators Hmga2 and Igfbp2. (E) Short interspersed element (SINE) containing IncRNAs can bind to UTR region of Cdc6 and Traf6 mRNAs and promote their decay at different stages of muscle differentiation. 
controlling the hierarchy within the myogenic gene regulatory network.

The transcription factor Yin Yang 1 (YY1) is another important regulator of myogenesis at multiple levels [73-77]. By comparing YY1 ChIP-seq results in proliferating and differentiated $\mathrm{C} 2 \mathrm{C} 12$ muscle cells, a number of lncRNAs regulated by YY1 (YY1-associated muscle lincRNAs or Yams) have been recently identified [65]. Yams display distinct expression patterns during muscle differentiation and affect myogenesis differently (Table1). For example, while $\mathrm{Yam}-2$ and -3 promote $\mathrm{C} 2 \mathrm{C} 12$ muscle differentiation, Yam-1 and -4 inhibit it [65]. The mechanism of action of Yam-1 was investigated in more detail. Yam-1 is a single exon transcript, regulated during in vitro and in vivo myogenesis and equally distributed in the nucleus and cytoplasm. Throughout development, in muscle regeneration and in tissue culture, Yam-1 is downregulated during terminal muscle differentiation [65]. Yam-1 knockdown promotes muscle differentiation in tissue culture and accelerates regeneration following muscle injury in vivo [65]. Importantly, Yam-1 knockdown rescues the myogenic defects caused by YY1 overexpression indicating that Yam-1 is an important mediator of YY1 activity in muscle [65]. Silencing of Yam-1 reduces the expression of several nearby genes, suggesting that it could be a positive cis-regulator of surrounding genes similar to eRNAs (Figure 1B) [65]. One of the nearby genes co-regulated with Yam-1 encodes for miR-715, a miRNA targeting $W n t 7 b$. Since Wnt signaling is a critical modulator of skeletal muscle formation [78], it is tempting to speculate that Yam-1 could function, at least in part, by activating $m i R$ 715 in cis leading to $W n t 7 b$ downregulation.

Besides regulating chromatin accessibility like eRNAs, nuclear lncRNAs can also control gene expression by directly affecting the activity of sequence-specific transcription factors. This is the case for steroid receptor RNA activator (SRA) [79], the first example of IncRNA regulating myogenesis [62]. SRA likely functions as a scaffold, bringing together multiple factors that modulate gene expression [80] including the master regulator of muscle differentiation MyoD (Figure 2B and Table1) [62]. In muscle, a complex composed by $S R A$, MyoD and the RNA helicases p68 and p72 has been identified (Figure 2B) [62]. Knockdown and overexpression studies indicate that p68/ p72 and SRA are coactivators required for the transcription of a subset of MyoD target genes and for muscle differentiation [62]. The SRA gene produces multiple transcripts through alternative splicing. While retention of intron 1 gives rise to the non protein-coding SRA transcript, splicing of the intron creates an open reading frame that generates the SRA protein (SRAP) [81]. The ratio between the coding and noncoding $S R A$ transcripts varies during muscle differentiation with SRAP mRNA being more abundant in myoblasts and $S R A$ lncRNA being the predominant isoform in myotubes [63]. SRAP works at least in part by regulating SRA lncRNA coactivator function. Indeed, SRAP is an RNA-binding protein that specifically binds $S R A$ lncRNA, thus preventing $S R A$-mediated regulation of $\mathrm{MyoD}$ transcriptional activity [63]. Hence, the correct balance between coding and noncoding $S R A$ molecules is important for normal muscle differentiation. Intriguingly, aberrant $S R A$ splicing is present in myotonic dystrophy patients. Whether impaired splicing of $S R A$ contributes to the pathogenesis of muscular dystrophy remains to be elucidated [63].

\section{Subnuclear structure-specific IncRNAs}

A number of lncRNAs are enriched in and contribute to organize specific subnuclear domains (Figure 1E) [82-88]. The IncRNA Malat1 is enriched in nuclear speckles, abundantly expressed in cancer cells and a strong predictor of tumor metastasis [89]. Malat1 has been shown to regulate gene transcription and pre-mRNA splicing by respectively interacting with the epigenetic repressor Polycomb protein Cbx4 [39] and with the SR family of splicing factors (Figure 2C and Table 1) [33]. Malat1 is upregulated during early differentiation of $\mathrm{C} 2 \mathrm{C} 12$ mouse myoblasts and primary human skeletal muscle cells, while its knockdown leads to suppression of myoblast proliferation by arresting cells in the G0/G1 phase [59], suggesting a role for Malat1 in the transition from the proliferative phase to the permanent cell cycle exit, as well as in the commitment to differentiation. Intriguingly, Malat1 has been recently identified as a novel downstream target of myostatin [59], an important regulator of myoblast proliferation, differentiation and skeletal muscle mass [90]. Future work will indicate how relevant Malat1 is for myostatin activity.

\section{Imprinted IncRNAs}

The Dlk1-Dio3 region is a very complex, imprinted locus involved in tissue growth regulation and human cancers [91]. Aberrant repression of the Dlk1-Dio3 imprinted cluster is present in most induced pluripotent stem cell (iPSC) lines and is responsible for the failure of iPSCs to form viable mice [92]. Intriguingly, postnatal aberrant expression of this locus is responsible for muscle hypertrophy in mouse and sheep [93,94]. The locus contains proteincoding RNAs, IncRNAs, miRNAs and snoRNAs expressed from either the paternal or the maternal allele. Several of the IncRNAs transcribed from the Dlk1-Dio3 region are enriched in the nucleus and have been reported to bind to Polycomb Repressive Complex 1 (PRC1), PRC2 and other epigenetic repressors [95-97]. Expression of the various Dlk1-Dio3 transcripts is reciprocally regulated. For example, the Glt2/Meg3 lncRNA binds to PRC2 recruiting it to the Dlk1-Dio3 locus to repress the protein-coding gene Dlk1 and the lncRNA Gtl2-as (Figure 2C and Table 1). 
Consistently, Glt2/Meg3 knockdown leads to a decreased PRC2 recruitment at the Dlk1 promoter with subsequent increased expression of Dlk1 and Gtl2-as [95]. During development, Gtl2/Meg3 is abundantly expressed in the paraxial mesoderm suggesting a role in myogenesis [55]. Indeed, Gtl2/Meg3 knockout mice develop skeletal muscle developmental defects along with perinatal death [56], promoting Gtl2/Meg3 as an example of a nuclear, cisacting lncRNA regulating muscle development.

H19 was the first lncRNA described in mammalian cells [98]. It is transcribed from the maternal allele of the H19/ Igf 2 locus producing a lncRNA predominantly enriched in the cytoplasm [98]. H19 is highly expressed in developing embryo and adult muscle in human and mouse [99,100], and is upregulated during myoblast differentiation and muscle regeneration [57,101]. H19 works at multiple levels. Through binding to the PRC2 epigenetic repressor complex [95], H19 can mediate the transcriptional repression of Igf2 (Figure 2C) [102,103]. Moreover, H19 can bind Igf2 mRNA binding-protein (IMP) family members to regulate Igf2 post-transcriptionally [104]. Also, H19 contains several binding sites for the let-7 family of microRNAs suggesting that H19 may act as a miRNA sponge for let-7 (Figure 2D and Table 1) [57]. Among let-7 targets, Hmga2 and Igfbp2 have an important role in myoblasts proliferation and myogenesis but must be downregulated to allow the formation of multinucleated myofibers (Figure 2D) [105]. Finally, H19 exon 1 encodes the conserved microRNAs miR-675-3p and miR-675-5p [106]. Recent results indicate that, by targeting Smad1, Smad5, and $C d c 6$, these miRNAs play an important role in the skeletal muscle differentiation and regeneration activities associated to $H 19$ [101].

\section{LncRNAs containing repetitive sequences controlling mRNA decay}

Short interspersed elements (SINEs) are among the most abundant repetitive sequences in mammalian genomes [107]. While initially thought of as 'junk' DNA, SINEs can be transcribed as individual elements by RNA polymerase III or as part of longer transcripts synthesized by RNA polymerase II and they can regulate gene expression by diverse mechanisms $[41,108]$. It has recently been discovered that a SINE within the 3' UTR of a protein-coding RNA can form intermolecular base pairing with a partially complementary SINE within one or more lncRNAs [43,64]. Extensive yet imperfect stretches of double-stranded RNA (dsRNA) can be bound at multiple sites by dsRNA-binding proteins, including Staufen 1 and 2 (STAU1 and STAU2). Staufen recruitment activates Staufen-mediated mRNA decay (SMD), an important mRNA degradation process in mammalian cells. Using this mechanism, lncRNAs containing SINEs regulate the stability of several mRNAs encoding for proteins with a role in muscle differentiation, including Cdc6 and Traf6 (Figure 2E and Table 1) [64]. Both STAU1 and STAU2 interact directly with the ATPdependent RNA helicase UPF1, a key SMD factor, enhancing its helicase activity to promote effective SMD. Because both SMD and the mechanistically related nonsense-mediated mRNA decay (NMD) employ UPF1, SMD and NMD are competitive pathways. This competition plays an important role in the control of muscle differentiation. Indeed, during myogenesis, the efficiency of NMD decreases while the efficiency of SMD increases. Interestingly, Myogenin and PAX3 are differentially targeted by these two pathways of degradation and this different susceptibility contributes to their relative abundance during differentiation. PAX3 mRNA is an SMD target and its increased decay promotes myogenesis, whereas decreased degradation of the NMD target Myogenin is required for myogenesis [109]. Importantly, since close to one third of all lncRNAs contains at least one SINE [64,110], lncRNAs containing SINE sequences could be at the heart of many physiologically important processes in addition to myogenesis.

\section{LncRNAs in muscle diseases}

Growing evidence shows that the vast majority of diseaseassociated genetic variations occur in the noncoding portion of the genome. In fact, whereas only $7 \%$ of diseaseassociated SNPs localize in protein-coding exons, the remaining 93\% arise in noncoding areas of the genome, of which $43 \%$ fall in intergenic regions [111]. Considering the extensive transcription of these areas, it is reasonable to predict that a significant and yet unknown number of lncRNAs are involved in a variety of human diseases. LncRNAs can either have a primary role in the pathogenesis of a disease or rather act as modulators of disease penetrance, explaining, at least in part, the inter-personal variability observed in virtually every disorder. So far, the contribution of lncRNAs to disease has mostly been investigated in cancer and neurological disorders [112-114] but the first examples of lncRNA involved in myopathies are now unveiled. Here, we focus on the recent discoveries regarding the role of lncRNAs in Duchenne muscular dystrophy and facioscapulohumeral muscular dystrophy.

\section{Duchenne muscular dystrophy}

Duchenne muscular dystrophy (DMD) is the most common and severe myopathy affecting 1:3,500 males. It is inherited in an X-linked recessive manner but, in very rare cases, heterozygous females can be mildly affected [115]. DMD is characterized by severe muscle wasting from early childhood that usually arises in leg and pelvic muscles and later extends to the trunk of the body, compromising the heart and respiratory muscles. DMD is caused by a variety of out-of-frame mutations in the $d y s$ trophin $(D M D)$ gene encoded on the $\mathrm{X}$ chromosome 
(Xp21.2) resulting in the lack of a functional dystrophin protein in skeletal muscle. With 79 exons and $2.4 \mathrm{Mb}$ in size, $D M D$ is the largest gene of our genome and up to 2,900 types of mutations have been reported in DMD patients so far $[116,117]$. Despite the mutations triggering the disease being well characterized, the regulation of dystrophin is in part unknown and appears much more complex than previously thought. Moreover, the inter-individual variability in the severity and the disease progression is only partially explained by the types of mutations and the occurrence of female patients remains enigmatic. Therefore, the regulation of $D M D$ is an area of intense research that in the last few years has led to the characterization of miRNA and lncRNA involvement [118].

Using custom-made tiling arrays, 14 lncRNAs transcribed from intronic sequences of the DMD gene both in sense and antisense orientations were recently identified [119]. These lncRNAs are expressed concomitantly with dystrophin in at least one of the tissues that normally express it: skeletal muscle, heart and brain [119]. Ectopic expression and promoter binding assays suggest that the lncRNAs can function in trans by downregulating the expression of specific dystrophin isoforms targeting their promoters (Figure 3A). Interestingly, an inverse correlation was found between the levels of dystrophin and a subset of lncRNAs in female carriers, both symptomatic and asymptomatic [119]. It remains to be investigated if these lncRNAs act in an allele-specific manner or whether they may also modulate the expression of the wild type dystrophin allele in female carriers. Additionally, it would be interesting to define how different
$D M D$ mutations may impact the expression of the lncRNAs.

The mutations occurring in DMD patients could also deregulate the expression of lncRNAs located outside the dystrophin gene or could even give rise to new lncRNAs as a result of translocation events. This could modulate the severity of the muscle degeneration or contribute to the development of additional symptoms such as the neurological complications observed in around one third of the patients $[120,121]$. A single case study recently published explores this hypothesis and describes how an intrachromosomal inversion $(\operatorname{inv}(\mathrm{X}) \mathrm{p} 21.2 ; \mathrm{q} 28)$ disrupts the novel lncRNA KUCG1 in a DMD patient with moderate mental retardation [122]. KUCG1 is a 648-bp nuclear lncRNA expressed in a tissue specific manner [122]. Since it is normally expressed in the brain, its deregulation could contribute to the neurological impairment of the patient [122] as already reported for other pathologies [114]. Although a functional characterization of this transcript has not been performed, this study underscores the pathological potential of mutations in noncoding loci that often follow genomic rearrangements.

Another lncRNA associated with DMD is long intergenic noncoding RNA-muscle differentiation 1 (linc-MD1) [46]. Linc-MD1 is a muscle-specific lncRNA required to activate late stages of the myogenic program. Linc-MD1 is a cytoplasmic ceRNA that acts as a molecular sponge for miR-133 and miRNA-135 (Figure 3B and Table 1) [46]. Through this mechanism, linc-MD1 promotes the expression of myocyte-specific enhancer factor 2C (MEF2C) and mastermind-like protein 1 (MAML1), two transcription

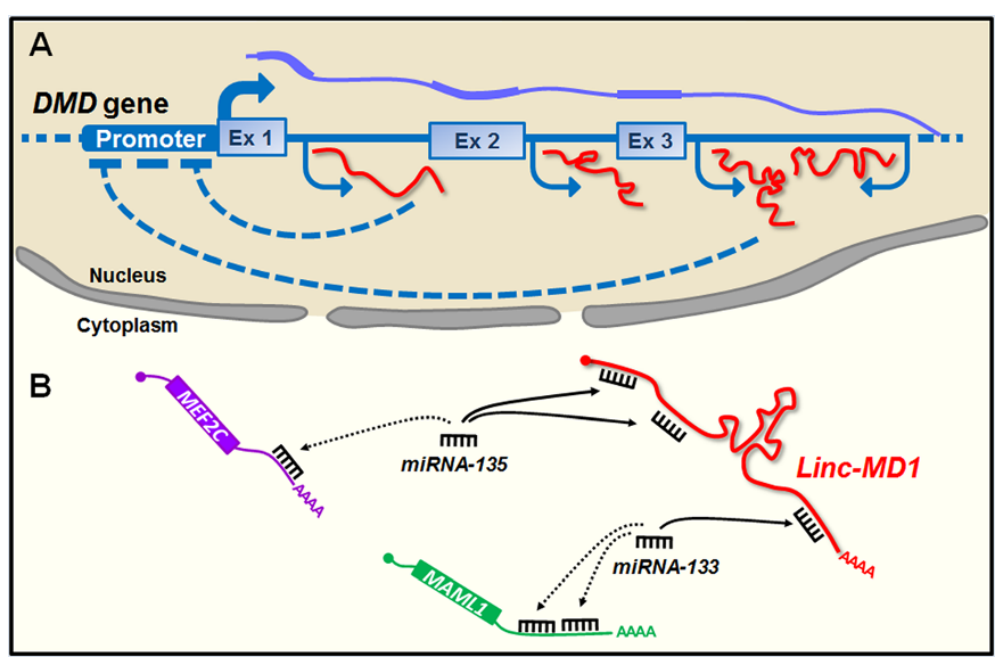

Figure 3 Proposed roles for long noncoding RNAs (IncRNAs) in Duchenne muscular dystrophy. (A) In the nucleus, sense and antisense transcription from intronic sequences of the dystrophin (DMD) gene gives rise to IncRNAs that play a repressive effect at specific DMD promoters. (B) In the cytoplasm, the muscle specific IncRNA linc-MD1 acts as a competitive endogenous RNA (ceRNA) by sequestering miRNAs away from their target mRNAs. Linc-MD1 contributes to muscle differentiation by sponging miRNA-135 and -133 , and thus promoting the expression of MEF2C and MAML1. Linc-MD1 is strongly reduced in muscle cells from DMD patients. 
factors with an important role in muscle differentiation (Figure 3B) [46]. Interestingly, the levels of linc-MD1 are strongly reduced in primary myoblasts of DMD patients and its ectopic expression rescues the myogenic differentiation potential of these cells, restoring the correct expression pattern of MAML1, MEF2C, MYOG and MHC [46]. Linc-MD1 can have a double life as lncRNA or as miRNA, since its primary transcript harbors the pri-miR-133b sequence. The balance between linc-MD1 and miR-133 biogenesis is regulated by HuR, an RNA-binding protein with a crucial role in myogenesis (Table 1) [123]. Moreover, HuR facilitates the linc-MD1-miRNA interaction, enhancing its sponge activity, thus affecting this ceRNA circuitry potentially relevant for DMD [58].

\section{Facioscapulohumeral muscular dystrophy}

Facioscapulohumeral muscular dystrophy (FSHD) is the third most common muscular dystrophy $(1: 14,000)$. FSHD is transmitted in an autosomal dominant manner and affects both sexes but presents a gender bias, as males are usually more severely affected [124]. FSHD displays a more restricted pattern of muscle weakness compared to DMD, mainly confined to the facial mimic and shoulder girdle muscles but extending to abdominal and leg muscles in the most severe cases $[125,126]$. The genetic lesion involved in FSHD is unusual as it does not target a protein-coding gene, but rather affects the copy number of the $3.3 \mathrm{~kb}$ macrosatellite D4Z4 mapping at the subtelomeric region of chromosome 4 (4q35) [127]. In the general population, D4Z4 copy number is highly polymorphic, displaying 11 to more than 100 units $[128,129]$. On the contrary, FSHD patients carry deletions reducing D4Z4 copy number between one and ten units $[129,130]$. D4Z4 deletion is associated with a profound change in the epigenetic status of the $4 \mathrm{q} 35$ region [131]. A recently identified lncRNA plays a key role in this transition [37]. In healthy subjects, the FSHD locus is under a repressive chromatin status, with high levels of DNA methylation, histone de-acetylation and enrichment for repressive histone marks such as H2Aub1, H3K9me3 and H3K27me3. Indeed, D4Z4 has been recently identified as a novel Polycomb (PcG) target region, suggesting that the presence of a high number of D4Z4 units leads to the extensive recruitment of PcG and the consequent repression of $4 \mathrm{q} 35$ genes in healthy subjects (Figure 4). In FSHD patients, instead, the reduction in number of D4Z4 units under a critical threshold leads to a reduced PcG binding with decreased levels of H3K27me3, particularly in the region immediately proximal to the D4Z4 repeat array. As a result, this region becomes more prone to transcription and gives rise to the activatory lncRNA $D B E-T$. $D B E-T$ is mainly produced in FSHD patients and mediates the aberrant activation of the FSHD locus [37]. $D B E-T$ is a nuclear transcript that acts in cis as it remains associated with the chromatin of the FSHD locus (Figure 4) [37]. DBE-T directly binds to the Trithorax (TrxG) protein ASHL1 recruiting it to the FSHD locus where it mediates the accumulation of H3K36me2 [37], a histone modification that counteracts PcG repressive activity [132-134]. Consequently, this leads to altered higher

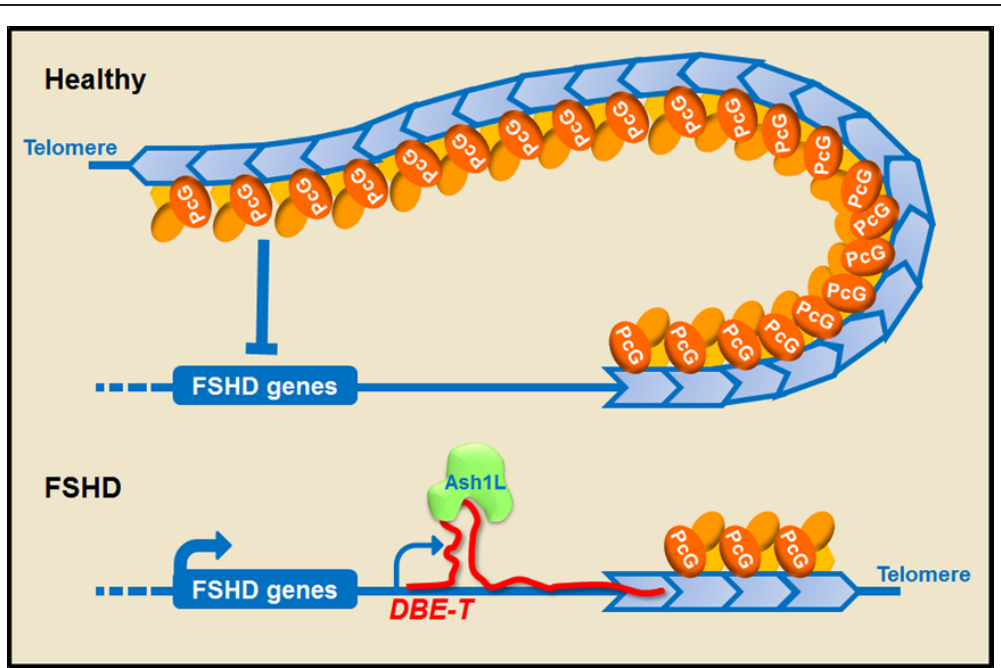

Figure 4 Role of DBE-T long noncoding RNA (IncRNA) in facioscapulohumeral muscular dystrophy (FSHD). In healthy individuals, the D4Z4 array displays from 11 to more than 100 units and is extensively bound by Polycomb group proteins (PcG), leading to the repression of the locus. In FSHD patients, the reduction of D4Z4 copy number to below 11 units causes decreased PcG binding and hence reduced silencing. This allows the transcription of the InCRNA DBE-T that remains associated to the FSHD locus and recruits the TrXG protein ASHL1 leading to activation of FSHD candidate genes. 
order chromatin organization and derepression of FSHD candidate genes localized nearby the D4Z4 array and unleashing FSHD pathogenesis [37].

\section{Conclusion}

It is increasingly evident that the functional repertoire of metazoan genomes extends far beyond protein-coding genes. A growing body of genetic and biochemical work indicates that long noncoding RNAs are important members of the complex muscle regulatory network, being engaged in diverse activities crucial for myogenesis. However, there is still a substantial gap between the expanding list of muscle lncRNAs and the precise molecular tasks they fulfill in the control of muscle differentiation. Moreover, the functional characterization of lncRNAs in muscular dystrophy is still in its infancy. Nevertheless, there is little doubt that results from such studies will significantly contribute to the formulation of specific and complementary diagnostic and therapeutic strategies for muscle wasting diseases.

\begin{abstract}
Abbreviations
ceRNA: competing endogenous RNA; ${ }^{C E} \mathrm{RNA}$ : core enhancer RNA; ChIPseq: chromatin immunoprecipitation sequencing; DBE-T: D4Z4 binding element transcript; DMD: Duchenne muscular dystrophy; DMD: dystrophin gene; ${ }^{\mathrm{DRR}} \mathrm{RNA}$ : distal regulatory region RNA; dsRNA: double-stranded RNA; eRNA: enhancer RNA; FSHD: facioscapulohumeral muscular dystrophy; GtI2/Meg3: gene trap locus 2/maternally expressed gene 3; H3K27ac: acetylated histone H3 lysine 27; H3K4me1: monomethyl histone H3 lysine 4; IMP: Igf2 mRNA binding-protein; iPSC: induced pluripotent stem cell; IRES: internal ribosomal entry site; lincMD1: long intergenic noncoding RNA-muscle differentiation 1; lincRNA: long intergenic noncoding RNA; IncRNA: long noncoding RNA; Malat1: metastasis associated lung adenocarcinoma transcript 1; MAML1: mastermind-like protein 1; MEF2: myocyte-specific enhancer factor-2; miRNA: microRNA; MRF4: myogenic regulatory factors; MyoD: myogenic differentiation; MyoG: myogenin; ncRNA: non protein-coding RNA; Nctc1: noncoding transcript 1; Neat1: nuclear enriched abundant transcript 1; NMD: nonsense-mediated mRNA decay; PcG: Polycomb group; piRNA: piwi-interacting RNA; PRC1 and PRC2: Polycomb Repressive Complex 1 and 2; RNAPII: RNA polymerase II; rRNA: ribosomal RNA; SINE: short interspersed element; siRNA: small interference RNA; SMD: Staufen-mediated mRNA decay; snoRNA: small nucleolar RNA; SNP: single nucleotide; snRNA: small nuclear RNA; SRA: steroid receptor RNA activator; SRAP: SRA protein; STAU1 and 2: Staufen 1 and 2; tRNA: transfer RNA; TrxG: Trithorax group; UTR: untranslated region; Yam: YY1-associated muscle; YY1: Yin Yang 1.
\end{abstract}

\section{Competing interests}

The authors declare that they have no competing interests.

\section{Authors' contributions}

MVN: manuscript writing, final approval of the manuscript. MJ: manuscript writing, final approval of the manuscript. DG: manuscript writing, final approval of the manuscript. All authors read and approved the final manuscript.

\section{Acknowledgements}

We apologize to our colleagues for the vastly incomplete documentation of their important contribution to the topics described in this review due to space limitations. We thank Dr. Anindya Dutta for sharing results before publication. The Gabellini laboratory is supported by the Association Française contre les Myopathies (AFM), the ERA-Net for Research on Rare Diseases (E-Rare-2), the European Research Council (ERC), the Italian Epigenomics Flagship Project, the Italian Ministry of Health and the FSHD Global Research Foundation.

D Gabellini is a Dulbecco Telethon Institute Senior Scientist.

$\mathrm{MJ}$ is recipient of a Dulbecco Telethon Institute International postdoctoral programme (DTI-IMPORT) fellowship.
Received: 14 February 2014 Accepted: 11 March 2014

Published: 31 March 2014

\section{References}

1. Liu G, Mattick JS, Taft RJ: A meta-analysis of the genomic and transcriptomic composition of complex life. Cell Cycle 2013, 12:2061-2072.

2. Djebali S, Davis CA, Merkel A, Dobin A, Lassmann T, Mortazavi A, Tanzer A Lagarde J, Lin W, Schlesinger F, Xue C, Marinov GK, Khatun J, Williams BA, Zaleski C, Rozowsky J, Roder M, Kokocinski F, Abdelhamid RF, Alioto T, Antoshechkin I, Baer MT, Bar NS, Batut P, Bell K, Bell I, Chakrabortty S, Chen X, Chrast J, Curado J, et al: Landscape of transcription in human cells. Nature 2012, 489:101-108.

3. Moss T, Langlois F, Gagnon-Kugler T, Stefanovsky V: A housekeeper with power of attorney: the rRNA genes in ribosome biogenesis. Cell Mol Life Sci 2007, 64:29-49.

4. Phizicky EM, Hopper AK: tRNA biology charges to the front. Genes Dev 2010, 24:1832-1860.

5. Kiss T: Biogenesis of small nuclear RNPs. J Cell Sci 2004, 117:5949-5951.

6. Ghildiyal M, Zamore PD: Small silencing RNAs: an expanding universe. Nat Rev Genet 2009, 10:94-108.

7. Watkins NJ, Bohnsack MT: The box C/D and H/ACA snoRNPs: key players in the modification, processing and the dynamic folding of ribosomal RNA. Wiley Interdiscip Rev RNA 2012, 3:397-414.

8. Derrien T, Guigo R, Johnson R: The long non-coding RNAs: a new (p)layer in the 'dark matter'. Front Genet 2011, 2:107.

9. Derrien T, Johnson R, Bussotti G, Tanzer A, Djebali S, Tilgner H, Guernec G, Martin D, Merkel A, Knowles DG, Lagarde J, Veeravalli L, Ruan X, Ruan Y, Lassmann T, Carninci P, Brown JB, Lipovich L, Gonzalez JM, Thomas M, Davis CA, Shiekhattar R, Gingeras TR, Hubbard TJ, Notredame C, Harrow J, Guigo R: The GENCODE v7 catalog of human long noncoding RNAs: analysis of their gene structure, evolution, and expression. Genome Res 2012, 22:1775-1789.

10. Kapranov P, Drenkow J, Cheng J, Long J, Helt G, Dike S, Gingeras TR: Examples of the complex architecture of the human transcriptome revealed by RACE and high-density tiling arrays. Genome Res 2005 15:987-997.

11. Hangauer MJ, Vaughn IW, McManus MT: Pervasive transcription of the human genome produces thousands of previously unidentified long intergenic noncoding RNAs. PLoS Genet 2013, 9:e1003569.

12. Guttman M, Amit I, Garber M, French C, Lin MF, Feldser D, Huarte M, Zuk O, Carey BW, Cassady JP, Cabili MN, Jaenisch R, Mikkelsen TS, Jacks T, Hacohen N, Bernstein BE, Kellis M, Regev A, Rinn JL, Lander E: Chromatin signature reveals over a thousand highly conserved large non-coding RNAs in mammals. Nature 2009, 458:223-227.

13. Mercer TR, Mattick JS: Structure and function of long noncoding RNAs in epigenetic regulation. Nat Struct Mol Biol 2013, 20:300-307.

14. Dieci G, Fiorino G, Castelnuovo M, Teichmann M, Pagano A: The expanding RNA polymerase III transcriptome. Trends Genet 2007, 23:614-622.

15. Kapranov P, Cheng J, Dike S, Nix DA, Duttagupta R, Willingham AT, Stadler PF, Hertel J, Hackermuller J, Hofacker IL, Bell I, Cheung E, Drenkow J, Dumais E, Patel S, Helt G, Ganesh M, Ghosh S, Piccolboni A, Sementchenko $\mathrm{V}$, Tammana $\mathrm{H}$, Gingeras TR: RNA maps reveal new RNA classes and a possible function for pervasive transcription. Science 2007, 316:1484-1488.

16. Cabili MN, Trapnell C, Goff L, Koziol M, Tazon-Vega B, Regev A, Rinn JL: Integrative annotation of human large intergenic noncoding RNAs reveals global properties and specific subclasses. Genes Dev 2011, 25:1915-1927.

17. Batista PJ, Chang HY: Long noncoding RNAs: cellular address codes in development and disease. Cell 2013, 152:1298-1307.

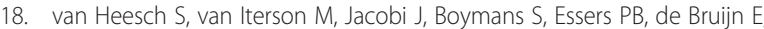
Hao W, Macinnes AW, Cuppen E, Simonis M: Extensive localization of long noncoding RNAs to the cytosol and mono- and polyribosomal complexes. Genome Biol 2014, 15:R6.

19. Penny GD, Kay GF, Sheardown SA, Rastan S, Brockdorff N: Requirement for Xist in X chromosome inactivation. Nature 1996, 379:131-137.

20. Pandey RR, Mondal T, Mohammad F, Enroth S, Redrup L, Komorowski J, Nagano T, Mancini-Dinardo D, Kanduri C: Kcnq1ot1 antisense noncoding RNA mediates lineage-specific transcriptional silencing through chromatin-level regulation. Mol Cell 2008, 32:232-246. 
21. Nagano T, Mitchell JA, Sanz LA, Pauler FM, Ferguson-Smith AC, Feil R, Fraser $P$ The Air noncoding RNA epigenetically silences transcription by targeting G9a to chromatin. Science 2008, 322:1717-1720.

22. Chu C, Qu K, Zhong FL, Artandi SE, Chang HY: Genomic maps of long noncoding RNA occupancy reveal principles of RNA-chromatin interactions. Mol Cell 2011, 44:667-678.

23. Plath K, Fang J, Mlynarczyk-Evans SK, Cao R, Worringer KA, Wang H, de la Cruz CC, Otte AP, Panning B, Zhang Y: Role of histone H3 lysine 27 methylation in X inactivation. Science 2003, 300:131-135.

24. Bertani S, Sauer S, Bolotin E, Sauer F: The noncoding RNA Mistral activates Hoxa6 and Hoxa7 expression and stem cell differentiation by recruiting MLL1 to chromatin. Mol Cell 2011, 43:1040-1046.

25. Martianov I, Ramadass A, Serra Barros A, Chow N, Akoulitchev A: Repression of the human dihydrofolate reductase gene by a non-coding interfering transcript. Nature 2007, 445:666-670.

26. Maamar H, Cabili MN, Rinn J, Raj A: linc-HOXA1 is a noncoding RNA that represses Hoxa1 transcription in cis. Genes Dev 2013, 27:1260-1271.

27. Ng SY, Bogu GK, Soh BS, Stanton LW: The long noncoding RNA RMST interacts with SOX2 to regulate neurogenesis. Mol Cell 2013, 51:349-359.

28. Feng J, Bi C, Clark BS, Mady R, Shah P, Kohtz JD: The Evf-2 noncoding RNA is transcribed from the Dlx-5/6 ultraconserved region and functions as a Dlx-2 transcriptional coactivator. Genes Dev 2006, 20:1470-1484.

29. Li W, Notani D, Ma Q, Tanasa B, Nunez E, Chen AY, Merkurjev D, Zhang J, Ohgi K, Song X, Oh S, Kim HS, Glass CK, Rosenfeld MG: Functional roles of enhancer RNAs for oestrogen-dependent transcriptional activation. Nature 2013, 498:516-520.

30. Mousavi K, Zare H, Dell'orso S, Grontved L, Gutierrez-Cruz G, Derfoul A, Hager GL, Sartorelli V: eRNAs promote transcription by establishing chromatin accessibility at defined genomic loci. Mol Cell 2013, 51:606617

31. De Santa F, Barozzi I, Mietton F, Ghisletti S, Polletti S, Tusi BK, Muller H, Ragoussis J, Wei CL, Natoli G: A large fraction of extragenic RNA pol II transcription sites overlap enhancers. PLoS Biol 2010, 8:e1000384.

32. Orom UA, Derrien T, Beringer M, Gumireddy K, Gardini A, Bussotti G, Lai F, Zytnicki M, Notredame C, Huang Q, Guigo R, Shiekhattar R: Long noncoding RNAs with enhancer-like function in human cells. Cell 2010, 143:46-58.

33. Tripathi V, Ellis JD, Shen Z, Song DY, Pan Q, Watt AT, Freier SM, Bennett CF, Sharma A, Bubulya PA, Blencowe BJ, Prasanth SG, Prasanth KV: The nuclear-retained noncoding RNA MALAT1 regulates alternative splicing by modulating SR splicing factor phosphorylation. Mol Cell 2010, 39:925-938.

34. Barry G, Briggs JA, Vanichkina DP, Poth EM, Beveridge NJ, Ratnu VS, Nayler SP, Nones K, Hu J, Bredy TW, Nakagawa S, Rigo F, Taft RJ, Cairns MJ, Blackshaw S, Wolvetang EJ, Mattick JS: The long non-coding RNA Gomafu is acutely regulated in response to neuronal activation and involved in schizophrenia-associated alternative splicing. Mol Psychiatry 2013, 19:486-494.

35. Yin QF, Yang L, Zhang Y, Xiang JF, Wu YW, Carmichael GG, Chen LL: Long noncoding RNAs with snoRNA ends. Mol Cell 2012, 48:219-230.

36. Wang KC, Yang YW, Liu B, Sanyal A, Corces-Zimmerman R, Chen Y, Lajoie BR, Protacio A, Flynn RA, Gupta RA, Wysocka J, Lei M, Dekker J, Helms JA, Chang HY: A long noncoding RNA maintains active chromatin to coordinate homeotic gene expression. Nature 2011, 472:120-124.

37. Cabianca DS, Casa V, Bodega B, Xynos A, Ginelli E, Tanaka Y, Gabellini D: A long ncRNA links copy number variation to a polycomb/trithorax epigenetic switch in FSHD muscular dystrophy. Cell 2012, 149:819-831.

38. Mao YS, Sunwoo H, Zhang B, Spector DL: Direct visualization of the co-transcriptional assembly of a nuclear body by noncoding RNAs. Nat Cell Biol 2011, 13:95-101.

39. Yang L, Lin C, Liu W, Zhang J, Ohgi KA, Grinstein JD, Dorrestein PC, Rosenfeld MG: ncRNA- and Pc2 methylation-dependent gene relocation between nuclear structures mediates gene activation programs. Cell 2011, 147:773-788.

40. Beltran M, Puig I, Pena C, Garcia JM, Alvarez AB, Pena R, Bonilla F, de Herreros AG: A natural antisense transcript regulates Zeb2/Sip1 gene expression during Snail1-induced epithelial-mesenchymal transition. Genes Dev 2008, 22:756-769.

41. Carrieri C, Cimatti L, Biagioli M, Beugnet A, Zucchelli S, Fedele S, Pesce E, Ferrer I, Collavin L, Santoro C, Forrest AR, Carninci P, Biffo S, Stupka E,
Gustincich S: Long non-coding antisense RNA controls Uchl1 translation through an embedded SINEB2 repeat. Nature 2012, 491:454-457.

42. Yoon JH, Abdelmohsen K, Srikantan S, Yang X, Martindale JL, De S, Huarte M, Zhan M, Becker KG, Gorospe M: LincRNA-p21 suppresses target mRNA translation. Mol Cell 2012, 47:648-655.

43. Gong C, Maquat LE: IncRNAs transactivate STAU1-mediated mRNA decay by duplexing with 3' UTRs via Alu elements. Nature 2011, 470:284-288.

44. Kretz M, Siprashvili Z, Chu C, Webster DE, Zehnder A, Qu K, Lee CS, Flockhart RJ, Groff AF, Chow J, Johnston D, Kim GE, Spitale RC, Flynn RA, Zheng GX, Aiyer S, Raj A, Rinn JL, Chang HY, Khavari PA: Control of somatic tissue differentiation by the long non-coding RNA TINCR. Nature 2013, 493:231-235.

45. Poliseno L, Salmena L, Zhang J, Carver B, Haveman WJ, Pandolfi PP: A coding-independent function of gene and pseudogene mRNAs regulates tumour biology. Nature 2010, 465:1033-1038.

46. Cesana M, Cacchiarelli D, Legnini I, Santini T, Sthandier O, Chinappi M, Tramontano A, Bozzoni I: A long noncoding RNA controls muscle differentiation by functioning as a competing endogenous RNA. Cell 2011, 147:358-369.

47. Wang Y, Xu Z, Jiang J, Xu C, Kang J, Xiao L, Wu M, Xiong J, Guo X, Liu H: Endogenous miRNA sponge lincRNA-RoR regulates Oct4, Nanog, and Sox2 in human embryonic stem cell self-renewal. Dev Cell 2013, 25:69-80.

48. Hansen TB, Wiklund ED, Bramsen JB, Villadsen SB, Statham AL, Clark SJ, Kjems J: miRNA-dependent gene silencing involving Ago2-mediated cleavage of a circular antisense RNA. Embo J 2011, 30:4414-4422.

49. Memczak S, Jens M, Elefsinioti A, Torti F, Krueger J, Rybak A, Maier L, Mackowiak SD, Gregersen LH, Munschauer M, Loewer A, Ziebold U, Landthaler M, Kocks C, le Noble F, Rajewsky N: Circular RNAs are a large class of animal RNAs with regulatory potency. Nature 2013, 495:333-338,

50. Sauvageau M, Goff LA, Lodato S, Bonev B, Groff AF, Gerhardinger C, Sanchez-Gomez DB, Hacisuleyman E, Li E, Spence M, Liapis SC, Mallard W, Morse M, Swerdel MR, D'Ecclessis MF, Moore JC, Lai V, Gong G, Yancopoulos GD, Frendewey D, Kellis M, Hart RP, Valenzuela DM, Arlotta P, Rinn JL: Multiple knockout mouse models reveal lincRNAs are required for life and brain development. elife 2013, 2:e01749.

51. Braun T, Gautel M: Transcriptional mechanisms regulating skeletal muscle differentiation, growth and homeostasis. Nat Rev Mol Cell Biol 2011, 12:349-361.

52. Buckingham M, Rigby PWJ: Gene regulatory networks and transcriptional mechanisms that control myogenesis. Dev Cell 2014, 28:225-238.

53. Sabourin LA, Rudnicki MA: The molecular regulation of myogenesis. Clin Genet 2000, 57:16-25.

54. Luo W, Nie Q, Zhang X: MicroRNAs involved in skeletal muscle differentiation. J Genet Genomics 2013, 40:107-116.

55. Schuster-Gossler K, Bilinski P, Sado T, Ferguson-Smith A, Gossler A: The mouse Gtl2 gene is differentially expressed during embryonic development, encodes multiple alternatively spliced transcripts, and may act as an RNA. Dev Dyn 1998, 212:214-228.

56. Zhou Y, Cheunsuchon P, Nakayama Y, Lawlor MW, Zhong Y, Rice KA, Zhang L, Zhang X, Gordon FE, Lidov HG, Bronson RT, Klibanski A: Activation of paternally expressed genes and perinatal death caused by deletion of the Gtl2 gene. Development 2010, 137:2643-2652.

57. Kallen AN, Zhou XB, Xu J, Qiao C, Ma J, Yan L, Lu L, Liu C, Yi JS, Zhang H, Min W, Bennett AM, Gregory Rl, Ding Y, Huang Y: The imprinted H19 IncRNA antagonizes let-7 microRNAs. Mol Cell 2013, 52:101-112.

58. Legnini I, Morlando M, Mangiavacchi A, Fatica A, Bozzoni I: A feedforward regulatory loop between HuR and the long noncoding RNA linc-MD1 controls early phases of myogenesis. Mol Cell 2014, 53:506-514.

59. Watts R, Johnsen VL, Shearer J, Hittel DS: Myostatin-induced inhibition of the long noncoding RNA Malat1 is associated with decreased myogenesis. Am J Physiol Cell Physiol 2013, 304:C995-1001.

60. Sunwoo H, Dinger ME, Wilusz JE, Amaral PP, Mattick JS, Spector DL: MEN epsilon/beta nuclear-retained non-coding RNAs are up-regulated upon muscle differentiation and are essential components of paraspeckles. Genome Res 2009, 19:347-359.

61. Eun B, Sampley ML, Good AL, Gebert CM, Pfeifer K: Promoter cross-talk via a shared enhancer explains paternally biased expression of Nctc1 at the Igf2/H19/Nctc1 imprinted locus. Nucleic Acids Res 2013, 41:817-826.

62. Caretti G, Schiltz RL, Dilworth FJ, Di Padova M, Zhao P, Ogryzko V, Fuller-Pace FV, Hoffman EP, Tapscott SJ, Sartorelli V: The RNA helicases 
p68/p72 and the noncoding RNA SRA are coregulators of MyoD and skeletal muscle differentiation. Dev Cell 2006, 11:547-560.

63. Hube F, Velasco G, Rollin J, Furling D, Francastel C: Steroid receptor RNA activator protein binds to and counteracts SRA RNA-mediated activation of MyoD and muscle differentiation. Nucleic Acids Res 2011, 39:513-525.

64. Wang J, Gong C, Maquat LE: Control of myogenesis by rodent SINEcontaining IncRNAs. Genes Dev 2013, 27:793-804.

65. Lu L, Sun K, Chen X, Zhao Y, Wang L, Zhou L, Sun H, Wang H: Genomewide survey by ChIP-seq reveals YY1 regulation of lincRNAs in skeletal myogenesis. Embo J 2013, 32:2575-2588.

66. Kim TK, Hemberg M, Gray JM, Costa AM, Bear DM, Wu J, Harmin DA, Laptewicz M, Barbara-Haley K, Kuersten S, Markenscoff-Papadimitriou E, Kuhl D, Bito H, Worley PF, Kreiman G, Greenberg ME: Widespread transcription at neuronal activity-regulated enhancers. Nature 2010, 465:182-187.

67. Lai F, Orom UA, Cesaroni M, Beringer M, Taatjes DJ, Blobel GA, Shiekhattar R: Activating RNAs associate with Mediator to enhance chromatin architecture and transcription. Nature 2013, 494:497-501.

68. Lam MT, Cho H, Lesch HP, Gosselin D, Heinz S, Tanaka-Oishi Y, Benner C, Kaikkonen MU, Kim AS, Kosaka M, Lee CY, Watt A, Grossman TR, Rosenfeld MG, Evans RM, Glass CK: Rev-Erbs repress macrophage gene expression by inhibiting enhancer-directed transcription. Nature 2013, 498:511-515.

69. Hah N, Murakami S, Nagari A, Danko CG, Kraus WL: Enhancer transcripts mark active estrogen receptor binding sites. Genome Res 2013, 23:1210-1223.

70. Melo CA, Drost J, Wijchers PJ, van de Werken H, de Wit E, Oude Vrielink JA, Elkon R, Melo SA, Leveille N, Kalluri R, de Laat W, Agami R: eRNAs are required for p53-dependent enhancer activity and gene transcription. Mol Cell 2013, 49:524-535.

71. Tapscott SJ, Lassar AB, Weintraub H: A novel myoblast enhancer element mediates MyoD transcription. Mol Cell Biol 1992, 12:4994-5003.

72. Goldhamer DJ, Faerman A, Shani M, Emerson CP Jr: Regulatory elements that control the lineage-specific expression of myoD. Science 1992, 256:538-542.

73. Lee TC, Zhang Y, Schwartz RJ: Bifunctional transcriptional properties of YY1 in regulating muscle actin and c-myc gene expression during myogenesis. Oncogene 1994, 9:1047-1052.

74. Caretti G, Di Padova M, Micales B, Lyons GE, Sartorelli V: The Polycomb Ezh2 methyltransferase regulates muscle gene expression and skeletal muscle differentiation. Genes Dev 2004, 18:2627-2638.

75. Wang H, Hertlein E, Bakkar N, Sun H, Acharyya S, Wang J, Carathers M, Davuluri R, Guttridge DC: NF-kappaB regulation of YY1 inhibits skeletal myogenesis through transcriptional silencing of myofibrillar genes. Mol Cell Biol 2007, 27:4374-4387.

76. Blattler SM, Cunningham JT, Verdeguer F, Chim H, Haas W, Liu H, Romanino K, Ruegg MA, Gygi SP, Shi Y, Puigserver P: Yin Yang 1 deficiency in skeletal muscle protects against rapamycin-induced diabetic-like symptoms through activation of insulin/IGF signaling. Cell Metab 2012, 15:505-517.

77. Palacios D, Mozzetta C, Consalvi S, Caretti G, Saccone V, Proserpio V, Marquez VE, Valente S, Mai A, Forcales SV, Sartorelli V, Puri PL: TNF/ p38alpha/polycomb signaling to Pax7 locus in satellite cells links inflammation to the epigenetic control of muscle regeneration. Cell Stem Cell 2010, 7:455-469.

78. von Maltzahn J, Chang NC, Bentzinger CF, Rudnicki MA: Wnt signaling in myogenesis. Trends Cell Biol 2012, 22:602-609.

79. Lanz RB, McKenna NJ, Onate SA, Albrecht U, Wong J, Tsai SY, Tsai MJ, O'Malley BW: A steroid receptor coactivator, SRA, functions as an RNA and is present in an SRC-1 complex. Cell 1999, 97:17-27.

80. Colley SM, Leedman PJ: Steroid Receptor RNA Activator - a nuclear receptor coregulator with multiple partners: insights and challenges. Biochimie 2011, 93:1966-1972.

81. Emberley E, Huang GJ, Hamedani MK, Czosnek A, Ali D, Grolla A, Lu B, Watson PH, Murphy LC, Leygue E: Identification of new human coding steroid receptor RNA activator isoforms. Biochem Biophys Res Commun 2003, 301:509-515.

82. Clemson CM, McNeil JA, Willard HF, Lawrence JB: XIST RNA paints the inactive $X$ chromosome at interphase: evidence for a novel RNA involved in nuclear/chromosome structure. J Cell Biol 1996, 132:259-275.
83. Sone M, Hayashi T, Tarui $\mathrm{H}$, Agata $\mathrm{K}$, Takeichi M, Nakagawa S: The mRNAlike noncoding RNA Gomafu constitutes a novel nuclear domain in a subset of neurons. J Cell Sci 2007, 120:2498-2506.

84. Clemson CM, Hutchinson JN, Sara SA, Ensminger AW, Fox AH, Chess A, Lawrence JB: An architectural role for a nuclear noncoding RNA: NEAT1 RNA is essential for the structure of paraspeckles. Mol Cell 2009, 33:717-726

85. Audas TE, Jacob MD, Lee S: Immobilization of proteins in the nucleolus by ribosomal intergenic spacer noncoding RNA. Mol Cell 2012, 45:147-157.

86. Ding DQ, Okamasa $K$, Yamane M, Tsutsumi C, Haraguchi T, Yamamoto $M$, Hiraoka Y: Meiosis-specific noncoding RNA mediates robust pairing of homologous chromosomes in meiosis. Science 2012, 336:732-736.

87. Vallot C, Huret C, Lesecque Y, Resch A, Oudrhiri N, Bennaceur-Griscelli A, Duret $L$, Rougeulle $C$ : XACT, a long noncoding transcript coating the active $\mathbf{X}$ chromosome in human pluripotent cells. Nat Genet 2013, 45:239-241.

88. Hacisuleyman E, Goff LA, Trapnell C, Williams A, Henao-Mejia J, Sun L, McClanahan P, Hendrickson DG, Sauvageau M, Kelley DR, Morse M, Engreitz J, Lander ES, Guttman M, Lodish HF, Flavell R, Raj A, Rinn JL: Topological organization of multichromosomal regions by the long intergenic noncoding RNA Firre. Nat Struct Mol Biol 2014, 21:198-206.

89. Schmidt LH, Spieker T, Koschmieder S, Schaffers S, Humberg J, Jungen $D$, Bulk E, Hascher A, Wittmer D, Marra A, Hillejan L, Wiebe K, Berdel WE, Wiewrodt R, Muller-Tidow C: The long noncoding MALAT-1 RNA indicates a poor prognosis in non-small cell lung cancer and induces migration and tumor growth. J Thorac Oncol 2011, 6:1984-1992.

90. Thomas M, Langley B, Berry C, Sharma M, Kirk S, Bass J, Kambadur R: Myostatin, a negative regulator of muscle growth, functions by inhibiting myoblast proliferation. J Biol Chem 2000, 275:40235-40243

91. da Rocha ST, Edwards CA, Ito M, Ogata T, Ferguson-Smith AC: Genomic imprinting at the mammalian Dlk1-Dio3 domain. Trends Genet 2008, 24:306-316.

92. Stadtfeld M, Apostolou E, Akutsu H, Fukuda A, Follett P, Natesan S, Kono T, Shioda T, Hochedlinger K: Aberrant silencing of imprinted genes on chromosome 12qF1 in mouse induced pluripotent stem cells. Nature 2010, 465:175-181

93. Davis E, Jensen CH, Schroder HD, Farnir F, Shay-Hadfield T, Kliem A, Cockett $\mathrm{N}$, Georges M, Charlier C: Ectopic expression of DLK1 protein in skeletal muscle of padumnal heterozygotes causes the callipyge phenotype. Curr Biol 2004, 14:1858-1862.

94. Freking BA, Murphy SK, Wylie AA, Rhodes SJ, Keele JW, Leymaster KA, Jirtle RL, Smith TP: Identification of the single base change causing the callipyge muscle hypertrophy phenotype, the only known example of polar overdominance in mammals. Genome Res 2002, 12:1496-1506.

95. Zhao J, Ohsumi TK, Kung JT, Ogawa Y, Grau DJ, Sarma K, Song JJ, Kingston RE, Borowsky M, Lee JT: Genome-wide identification of polycomb-associated RNAs by RIP-seq. Mol Cell 2010, 40:939-953.

96. Guttman M, Donaghey J, Carey BW, Garber M, Grenier JK, Munson G, Young G, Lucas AB, Ach R, Bruhn L, Yang X, Amit I, Meissner A, Regev A, Rinn $J L$, Root DE, Lander ES: lincRNAs act in the circuitry controlling pluripotency and differentiation. Nature 2011, 477:295-300.

97. Kaneko S, Bonasio R, Saldana-Meyer R, Yoshida T, Son J, Nishino K, Umezawa A, Reinberg D: Interactions between JARID2 and noncoding RNAs regulate PRC2 recruitment to chromatin. Mol Cell 2014, 53:290-300

98. Brannan $\mathrm{Cl}$, Dees EC, Ingram RS, Tilghman SM: The product of the H19 gene may function as an RNA. Mol Cell Biol 1990, 10:28-36.

99. Gabory A, Jammes H, Dandolo L: The H19 locus: role of an imprinted non-coding RNA in growth and development. Bioessays 2010, 32:473-480.

100. Onyango P, Feinberg AP: A nucleolar protein, H19 opposite tumor suppressor (HOTS), is a tumor growth inhibitor encoded by a human imprinted $\mathrm{H} 19$ antisense transcript. Proc Natl Acad Sci U S A 2011, 108:16759-16764.

101. Dey BK, Pfeifer K, Dutta A: The H19 long noncoding RNA gives rise to microRNAs miR-675-3p and miR-675-5p to promote skeletal muscle differentiation and regeneration. Genes Dev 2014, 28:491-501.

102. Ripoche MA, Kress C, Poirier F, Dandolo L: Deletion of the H19 transcription unit reveals the existence of a putative imprinting control element. Genes Dev 1997, 11:1596-1604.

103. Forne T, Oswald J, Dean W, Saam JR, Bailleul B, Dandolo L, Tilghman SM, Walter J, Reik W: Loss of the maternal H19 gene induces changes in lgf2 
methylation in both cis and trans. Proc Natl Acad Sci U S A 1997, 94:10243-10248.

104. Runge S, Nielsen FC, Nielsen J, Lykke-Andersen J, Wewer UM, Christiansen J: H19 RNA binds four molecules of insulin-like growth factor II mRNAbinding protein. J Biol Chem 2000, 275:29562-29569.

105. Li Z, Gilbert JA, Zhang Y, Zhang M, Qiu Q, Ramanujan K, Shavlakadze T, Eash JK, Scaramozza A, Goddeeris MM, Kirsch DG, Campbell KP, Brack AS, Glass DJ: An HMGA2-IGF2BP2 axis regulates myoblast proliferation and myogenesis. Dev Cell 2012, 23:1176-1188.

106. Cai $X$, Cullen BR: The imprinted $\mathrm{H} 19$ noncoding RNA is a primary microRNA precursor. Rna 2007, 13:313-316.

107. Casa V, Gabellini D: A repetitive elements perspective in Polycomb epigenetics. Front Genet 2012, 3:199.

108. Walters RD, Kugel JF, Goodrich JA: InvAluable junk: the cellular impact and function of Alu and B2 RNAs. IUBMB life 2009, 61:831-837.

109. Gong C, Kim YK, Woeller CF, Tang Y, Maquat LE: SMD and NMD are competitive pathways that contribute to myogenesis: effects on PAX3 and myogenin mRNAs. Genes Dev 2009, 23:54-66.

110. Kapusta A, Kronenberg Z, Lynch VJ, Zhuo X, Ramsay L, Bourque G, Yandell M, Feschotte C: Transposable elements are major contributors to the origin, diversification, and regulation of vertebrate long noncoding RNAs. PLoS Genet 2013, 9:e1003470.

111. Hindorff LA, Sethupathy P, Junkins HA, Ramos EM, Mehta JP, Collins FS, Manolio TA: Potential etiologic and functional implications of genomewide association loci for human diseases and traits. Proc Natl Acad Sci US A 2009, 106:9362-9367.

112. Pastori $C$, Wahlestedt $C$ : Involvement of long noncoding RNAs in diseases affecting the central nervous system. RNA Biol 2012, 9:860-870.

113. Cheetham SW, Gruhl F, Mattick JS, Dinger ME: Long noncoding RNAs and the genetics of cancer. Br J Cancer 2013, 108:2419-2425.

114. Niland CN, Merry CR, Khalil AM: Emerging roles for long non-coding RNAs in cancer and neurological Disorders. Front Genet 2012, 3:25

115. Soltanzadeh P, Friez MJ, Dunn D, von Niederhausern A, Gurvich OL, Swoboda KJ, Sampson JB, Pestronk A, Connolly AM, Florence JM, Finkel RS, Bonnemann CG, Medne L, Mendell JR, Mathews KD, Wong BL, Sussman MD, Zonana J, Kovak K, Gospe SM Jr, Gappmaier E, Taylor LE, Howard MT, Weiss $\mathrm{RB}$, Flanigan KM: Clinical and genetic characterization of manifesting carriers of DMD mutations. Neuromuscul Disord 2010, 20:499-504.

116. Leiden Open Variation Database. [http://www.dmd.nl/nmdb2/home.php? select_db=DMD]

117. UMD-DMD French Database. [http://www.umd.be/DMD/W_DMD/index html]

118. Erriquez D, Perini G, Ferlini A: Non-coding RNAs in muscle dystrophies. Int J Mol Sci 2013, 14:19681-19704.

119. Bovolenta M, Erriquez D, Valli E, Brioschi S, Scotton C, Neri M, Falzarano MS Gherardi S, Fabris M, Rimessi P, Gualandi F, Perini G, Ferlini A: The DMD locus harbours multiple long non-coding RNAs which orchestrate and control transcription of muscle dystrophin mRNA isoforms. PLoS One 2012, 7:e45328.

120. Sarrazin E, Hagen MV, Schara U, von Au K, Kaindl AM: Growth and psychomotor development of patients with Duchenne muscular dystrophy. Eur J Paediatr Neurol 2014, 18:38-44.

121. Pane $M$, Lombardo ME, Alfieri $P$, D'Amico A, Bianco F, Vasco G, Piccini G, Mallardi M, Romeo DM, Ricotti V, Ferlini A, Gualandi F, Vicari S, Bertini E, Berardinelli A, Mercuri E: Attention deficit hyperactivity disorder and cognitive function in Duchenne muscular dystrophy: phenotypegenotype correlation. J Pediatr 2012, 161:705-709. e701.

122. Tran TH, Zhang Z, Yagi M, Lee T, Awano H, Nishida A, Okinaga T, Takeshima Y, Matsuo M: Molecular characterization of an X(p21.2;q28) chromosomal inversion in a Duchenne muscular dystrophy patient with mental retardation reveals a novel long non-coding gene on Xq28. J Hum Genet 2013, 58:33-39.

123. von Roretz C, Beauchamp P, Di Marco S, Gallouzi IE: HuR and myogenesis: being in the right place at the right time. Biochim Biophys Acta 2011 1813:1663-1667.

124. Tonini MM, Passos-Bueno MR, Cerqueira A, Matioli SR, Pavanello R, Zatz M: Asymptomatic carriers and gender differences in facioscapulohumeral muscular dystrophy (FSHD). Neuromuscul Disord 2004, 14:33-38.

125. Shahrizaila N, Wills AJ: Significance of Beevor's sign in facioscapulohumeral dystrophy and other neuromuscular diseases. J Neurol Neurosurg Psychiatry 2005, 76:869-870.
126. Pandya S, King WM, Tawil R: Facioscapulohumeral dystrophy. Phys Ther 2008, 88:105-113.

127. Wijmenga C, Sandkuijl LA, Moerer P, van der Boorn N, Bodrug SE, Ray PN, Brouwer OF, Murray JC, van Ommen GJ, Padberg GW, Frants RR: Genetic linkage map of facioscapulohumeral muscular dystrophy and five polymorphic loci on chromosome 4q35-qter. Am J Hum Genet 1992, 51:411-415

128. Hewitt JE, Lyle R, Clark LN, Valleley EM, Wright TJ, Wijmenga C, van Deutekom JC, Francis F, Sharpe PT, Hofker M, Frants RR, Williamson R: Analysis of the tandem repeat locus D4Z4 associated with facioscapulohumeral muscular dystrophy. Hum Mol Genet 1994, 3:1287-1295.

129. Wijmenga C, Hewitt JE, Sandkuijl LA, Clark LN, Wright TJ, Dauwerse HG, Gruter AM, Hofker MH, Moerer P, Williamson R, van Ommen GJB, Padberg GW, Frants RR: Chromosome 4q DNA rearrangements associated with facioscapulohumeral muscular dystrophy. Nat Genet 1992, 2:26-30.

130. van Deutekom JC, Wijmenga C, van Tienhoven EA, Gruter AM, Hewitt JE, Padberg GW, van Ommen GJ, Hofker MH, Frants RR: FSHD associated DNA rearrangements are due to deletions of integral copies of a $3.2 \mathrm{~kb}$ tandemly repeated unit. Hum Mol Genet 1993, 2:2037-2042.

131. Neguembor MV, Gabellini D: In junk we trust: repetitive DNA, epigenetics and facioscapulohumeral muscular dystrophy. Epigenomics 2010, 2:271-287.

132. Schmitges FW, Prusty AB, Faty M, Stutzer A, Lingaraju GM, Aiwazian J, Sack R, Hess D, Li L, Zhou S, Bunker RD, Wirth U, Bouwmeester T, Bauer A, Ly-Hartig N, Zhao K, Chan H, Gu J, Gut H, Fischle W, Muller J, Thoma NH: Histone methylation by PRC2 is inhibited by active chromatin marks. Mol Cell 2011, 42:330-341.

133. Yuan W, Xu M, Huang C, Liu N, Chen S, Zhu B: H3K36 methylation antagonizes PRC2-mediated H3K27 methylation. J Biol Chem 2011 286:7983-7989.

134. Dorighi KM, Tamkun JW: The trithorax group proteins Kismet and ASH1 promote H3K36 dimethylation to counteract Polycomb group repression in Drosophila. Development 2013, 140:4182-4192.

doi:10.1186/2044-5040-4-8

Cite this article as: Neguembor et al:: Long noncoding RNAs, emerging players in muscle differentiation and disease. Skeletal Muscle 2014 4:8.

\section{Submit your next manuscript to BioMed Central and take full advantage of:}

- Convenient online submission

- Thorough peer review

- No space constraints or color figure charges

- Immediate publication on acceptance

- Inclusion in PubMed, CAS, Scopus and Google Scholar

- Research which is freely available for redistribution

Submit your manuscript at www.biomedcentral.com/submit
C) Biomed Central 